\title{
Krzysztof Sołek
}

\section{Thixoforming of high-melting-point alloys}

\author{
Procesy formowania tiksotropowego \\ stopów metali wysokotopliwych
}

\begin{abstract}
Processing of steel in the semi-solid state concerns mainly continuous casting and thixoforming processes. Continuous casting is usually applied within the confines of steel making processes. Due to stringent process requirements, thixotropic forming of steel alloys has not been practically applied in industry yet. However, it is believed that this method could be used for forming selected products. Thixoforming could be treated as alternative method of production for forging techniques in the case non-plastic alloys. In this paper the method of development of globular microstructure, thixoforming process and analysis of rheological properties of selected steels were described.
\end{abstract}

Keywords: steels, thixoforming, rheological properties, viscosity, thixotropy

\section{Streszczenie}

Procesy formowania tiksotropowego stopów aluminium oraz magnezu znajdują zastosowanie w praktyce przemysłowej. Ze stopów aluminium w ten sposób wykonuje się szereg elementów, między innymi na potrzeby przemysłu motoryzacyjnego. Kształtowanie w stanie stałociekłym stopów magnezu jest realizowane z wykorzystaniem technologii nazywanej thixomolding, pozwalającej kształtować elementy produkowane na potrzeby na przykład przemysłu elektronicznego. Procesom formowania tiksotropowego stopów metali wysokotopliwych takich jak stale lub stopy Co-Cr-Ni towarzyszy szereg trudności powodowanych wysoką temperaturą formowania, dlatego tiksoformowanie tych stopów nie znalazło jak dotąd praktycznego zastosowania. Obecnie realizuje się szereg badań naukowych, których celem jest wyeliminowanie trudności technicznych oraz obniżenie kosztów tych procesów. W tej pracy zostały omówione metody rozwoju struktury globularnej, procesy formowania tiksotropowego oraz właściwości reologiczne wybranych stali.

Słowa kluczowe: stale, tiksoforming, właściwości reologiczne, lepkość, tiksotropia

\section{Introduction}

Semi-solid phase flow occurs during continuous casting mainly inside crystallizer and along metallurgical length. Distribution of velocity field influences on cooling process

Krzysztof Sołek Ph.D. Eng.: AGH University of Science and Technology, Faculty of Metals Engineering and Industrial Computer Science, Krakow, Poland; ksolek@metal.agh.edu.pl 
and segregation of alloys components. Among other things too high velocity near to mould walls can causes damage of it.

Due to the high mechanical and functional properties of steel forgings, they are largely used as parts of the drive units and sub-assemblies of suspensions in the automotive and machine building industries. The need for applying multi-impression forging, which multiplies the number of process operations, substantially affects the high cost of forging production. The energy and material consumption of the processes, high costs of the tools, and often the large number of necessary tools also affect the profitability of production [1]. Complex-shape components may also be manufactured with casting processes, but these processes do not guarantee high mechanical properties in each case, including the fatigue resistance of a finished product. At present, researchers dealing with metallurgy are becoming interested in the possibility of forming metal alloys in the thixotropic state (shortly called "thixoforming"). These are semi-solid metal-forming processes (SSM-Forming). Thixoforming processes have selected advantages of classic forging and casting processes, which gives them the technological and economic potential for the production of components with high mechanical properties and complex shapes. Compared to classic forging processes, semi-solid metal-forming processes enable the metal to be shaped with much-smaller pressures in a single-process operation. Thixotropic forging processes of steel alloys will allow the forged product market to be enriched and will provide a new category of steel forgings with thin-walled shapes and reduced weights. The industrial application of this innovative process is now limited to aluminum and magnesium alloys [2] due to their low solidification temperature (as compared to steel alloys) and the possibility of easy tool manipulation. Some covers, casings etc., used in the automotive and electronic industries (e.g., brake system parts, notebook casings, etc.) are manufactured with this method. Due to stringent process requirements, thixoforming of high-melting steel alloys has not been practically applied in industry as of yet. A similar situation concerns $\mathrm{Co}-\mathrm{Cr}$-Ni alloys. These alloys feature low plasticity and are generally cast. The final shape of the finished products of these alloys is obtained with costly machining processes [3]. Thixoforming processes may be an alternative method for forming these alloys [4].

The first work on this subject started in the early seventies of the $20^{\text {th }}$ century [5]. It was carried out by a group managed by M. Flemings of the Massachusetts Institute of Technology (USA). In this method, metal alloys were formed under the conditions of the solid and liquid phase coexistence. Additionally, these processes require a globular microstructure, sometimes called the "rheocast structure" in the literature. The occurrence of the globular microstructure is a result of the thixotropic properties of semi-solid metal alloys [5]. A microstructure like this can be obtained as a result of a number of various processes to which an alloy for thixoforming is subjected [5-11]. For ferrous alloys, this microstructure is generally a suspension of quasi-globular solid particles, with the austenite structure surrounded by the liquid phase. 
Many definitions of thixotropy exist in the literature [12]. The definition of this transformation may include a reversible transition of a gel (an alloy in which the solid phase exists in the form of a coherent skeleton submerged in the liquid phase) into a sol (an alloy with a globular structure), occurring as a result of mechanical impact (stirring, shocks). As a result, the spatial gel network is destroyed, which causes its fluidization (a drop in the apparent viscosity) or a transition into a sol. The mechanical impact causes the transformation of a dendritic structure into a globular structure. A break in deformation causes a re-construction of the solid-phase skeleton.

The objective of this research has been to construct models of forming processes of high melting point alloys in the semi-solid state, to identify conditions of globular structure formation, and to identify the rheological properties of semi-solid ferrous alloys. Within the confines of this work both structural and tool steels were investigated.

\section{Development of globular microstructure}

The first part of the research concerned defining the procedures and conditions for obtaining a globular microstructure conditional to the correct execution of the thixoforming process. The effectiveness of the SIMA (Strain Induced Melt Activated, Fig. 1) method applied to the development of a globular microstructure in steel alloys heated to the semi-solid state [13-15] was confirmed.

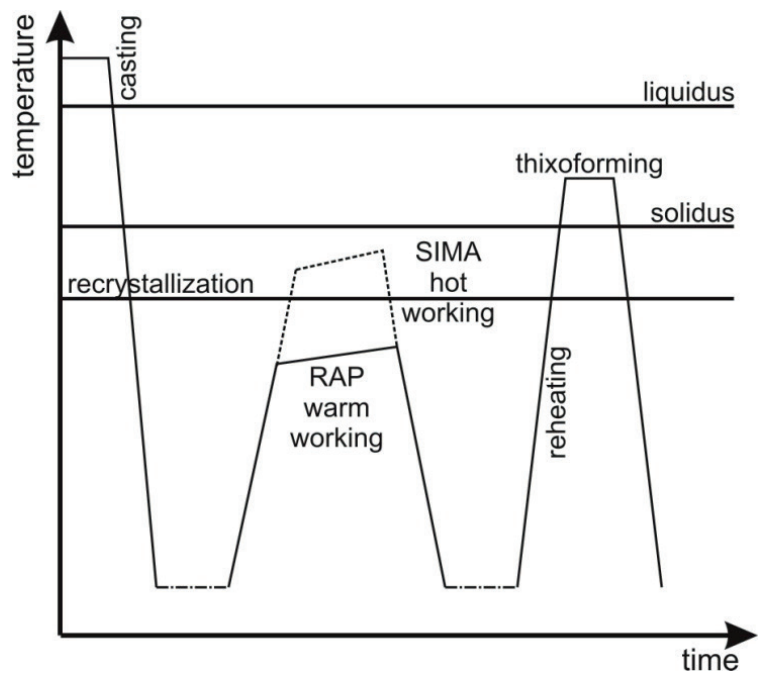

Fig. 1. Diagram of SIMA and RAP methods

The original accomplishment of the research was proving that hot-worked commercial steel alloys could be used in the thixoforming processes. This finding has a significant 
economic aspect, as the potential possibility of thixoforming processes to product parts made from steel substantially contributes to the reduction of costs of the whole process by omitting the costly procedures of globular structure preparation. The research was based on the selected steel alloys of grades HS6-5-2 (SW7M), X210Cr12 (NC11), 100Cr6 ( $Ł \mathrm{H} 15$ ). A Gleeble 3800 thermomechanical simulator and high-temperature furnaces allowing the samples to be heated up to $1500^{\circ} \mathrm{C}$ under a protective atmosphere were used for the analysis. The work performed at the Gleeble 3800 simulator concerned the analysis of microstructure development using axisymmetrical specimens (lengths of $120 \mathrm{~mm}$ and $12 \mathrm{~mm}$, diameter of $10 \mathrm{~mm}$ ). Axisymmetrical samples with the applied geometry are conventionally used to simulate the deformation and crystallization processes in continuous casting. The Gleeble simulator has a built-in sample resistance heating system using a control thermocouple. In the first stage of the work, the temperature distribution was determined in the analyzed samples in order to establish the mushy zone. The samples were fitted in cooled grips; therefore, the semi-solid state was only observed in the central part of these samples. Anyway, the temperature distribution was necessary to predict the dependence of the liquid phase fraction as a function of temperature. The obtained results allowed us to confirm, on the basis of metallographic analysis, the dependence of the liquid phase fraction on temperature, obtained on the basis of an DSC (Differential Scanning Calorymetry) analysis of the alloys investigated. The temperature distribution for the geometry of the samples tested was analyzed with numerical calculations. To this end, a numerical model implemented in the ADINA software was formulated. The heating model was based on the determination of electrical potential from the Laplace equation. The heat emitting on the actual resistance was determined from the Joule-Lenz law and added to the right-hand side of the thermal conductivity equation. In the case of samples $12 \mathrm{~mm}$ in length applied boundary conditions were shown in Figure 2. Figure 3 presents the computed temperature distributions in the samples tested on the Gleeble 3800 simulator.

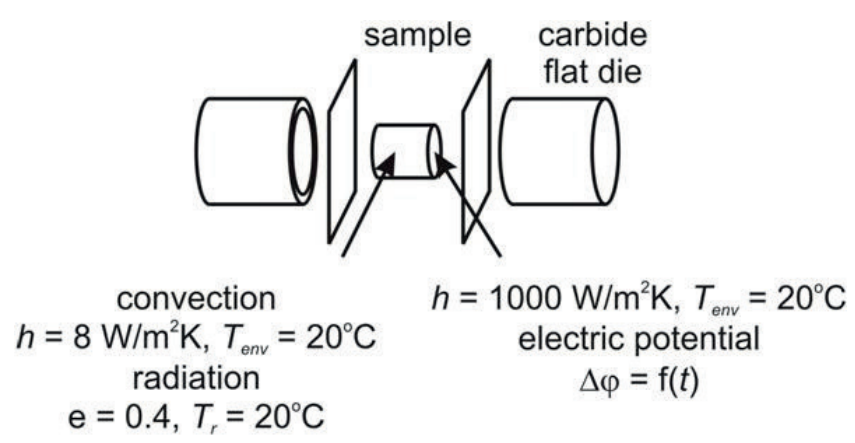

Fig. 2. Boundary conditions applied in numerical simulation of heating process of the samples $12 \mathrm{~mm}$ in length 


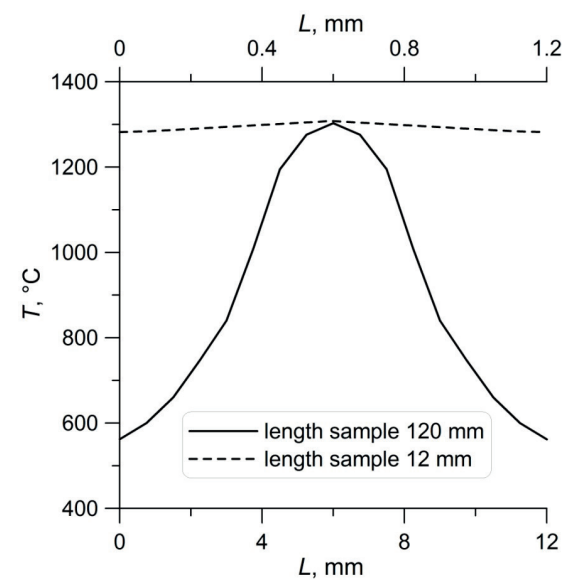

Fig. 3. Temperature distributions in samples tested on Gleeble simulator for assumed experiment temperature of $1300^{\circ} \mathrm{C}$ (length of first sample $-12 \mathrm{~mm}$, and second $-120 \mathrm{~mm}$ )

As a result of the conducted experiments [13-17], it was proven that it is possible to obtain a globular microstructure in semi-solid steel alloys previously subjected to hot working (the SIMA method) or made by sprayforming (Fig. 4).

a)

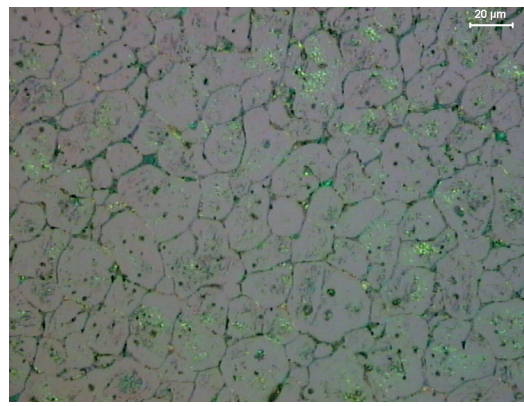

b)

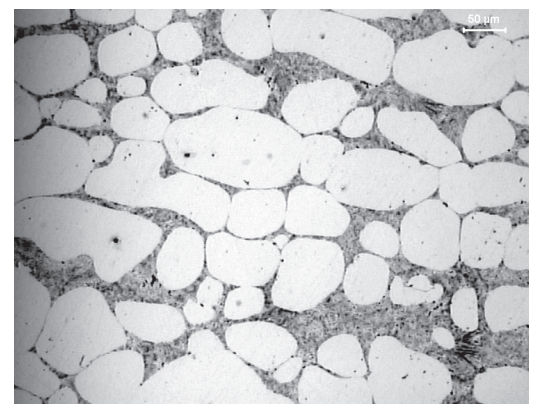

c)

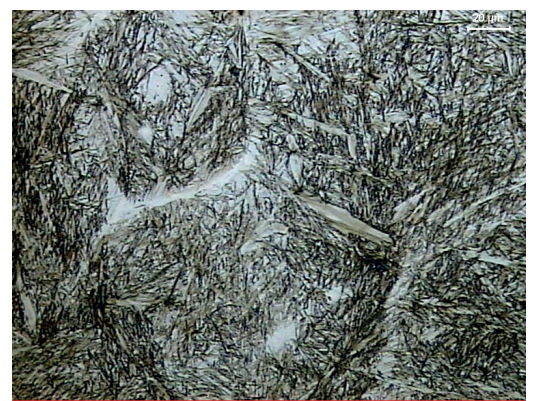

Fig. 4. Globular structure in steels: a) HS6-5-2 (SW7M) $-1270^{\circ} \mathrm{C}(\sim 0.15$ liquid fraction); b) X210Cr12 (NC11) $-1250^{\circ} \mathrm{C}(\sim 0.3$ liquid fraction); C) $100 \mathrm{Cr} 6$ ( $\mathrm{HH} 15)-1400^{\circ} \mathrm{C}(\sim 0.15$ liquid fraction) 


\section{Thixoforming processes of high-melting-point alloys}

The second group of objectives concerned the shaping of semi-solid alloys. The main assumption of the work was to use special instruments for this purpose, allowing the conditions of the potential processes of thixoforming ferrous alloys to be precisely mapped [15-17]. The instruments used were comprised a induction heater, steel mold and hydraulic press (Fig. 5). The hydraulic press enable high strain rate in order to obtain defectfree (incomplete filling caused by a deformation temperature drop below the solidus point) thixotropic forgings (die stampings). The thixoforming process of applicable part made from $100 \mathrm{Cr} 6(\mathrm{kH15})$ steel was carried out [17]. The input material was initially hot worked (the SIMA method) in order to develop the globular structure in the semi-solid state. Obtained stamping featured a globular microstructure.

In this part of the work successful steel thixoforming processes were conducted The scope of work included performing heating tests, assembling tools, programming accessories and conducting steel forming in the semi-solid state. The work included tests of steel sample heating to the temperature range between the liquidus and solidus, and examinations of the microstructure with optical and scanning microscopy. The obtained temperature distribution within the volume of the samples tested was sufficiently homogeneous to be subjected to the forming process. Within this item of the schedule a set of tools was used, corresponding to the geometric layout of a hydraulic press and an induction coil (Fig. 6). This set consisted of a steel two-part mold, heated with a band heater, and a stamp driven with a hydraulic cylinder in the press upper cross-bar. The feedstock was heated in the induction coil placed next to the hydraulic press. The mold was made of hot work-tool steel. For the experimental work, industrial equipment comprising a hydraulic press, induction heater and industrial robots was used (Fig. 5). Among others, it was proved that it was possible to design a stand for thixoforming of steel alloys based on the equipment available in the market.

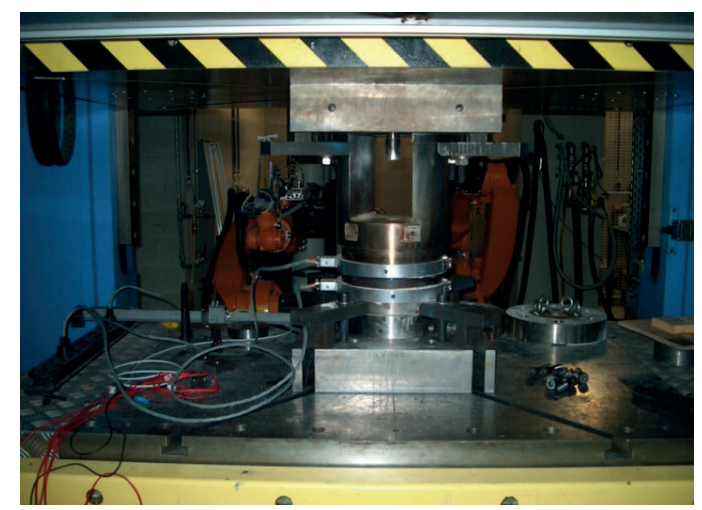

Fig. 5. Stand for steel thixoforming used in experiments constructed on basis of widely available components 


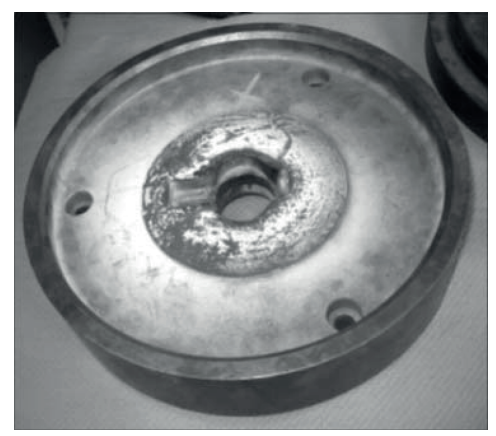

Fig. 6. Lower die with cavity having forging shape

The first part of experimental work was devoted to calibration of the inductive heating device generator. Three heating trials were executed for samples made of $100 \mathrm{Cr} 6$ steel. The third one was recognized as optimal. The validation of the heating was carried out on the basis of comparison of measured and assumed temperature. Temperatures were measured at two points; inside of sample and close to lateral surface (see Fig. 7). The validation of thermal distribution homogeneity was performed in this way. Finally, a three-step heating cycle was established. The heating rate equals $40^{\circ} \mathrm{C} / \mathrm{s}$ during first step, $20^{\circ} \mathrm{C} / \mathrm{s}$ during second and $1.5^{\circ} \mathrm{C} / \mathrm{s}$ during third. The profile of temperature versus time is shown in Figure 8. It is easy to observe that the temperature inhomogeneity is not higher than $10^{\circ} \mathrm{C}$. The microstructure of the heated sample shows the solid globular particles surrounded by liquid (Fig. 4c). Thus, such microstructure can be applied for thixoforming.

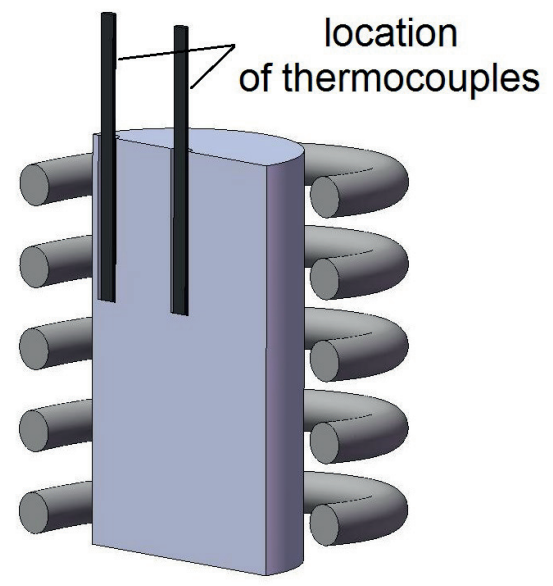

Fig. 7. Location of thermocouples during calibration of heating device, measurement of sample temperature at axis and by lateral surface 
a)

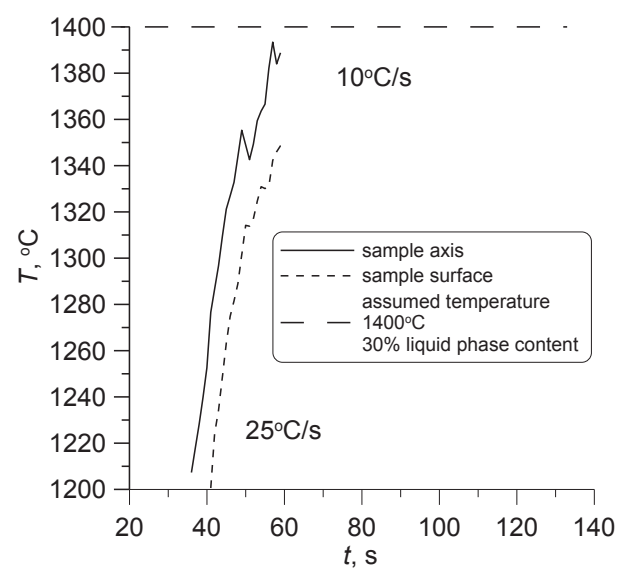

b)

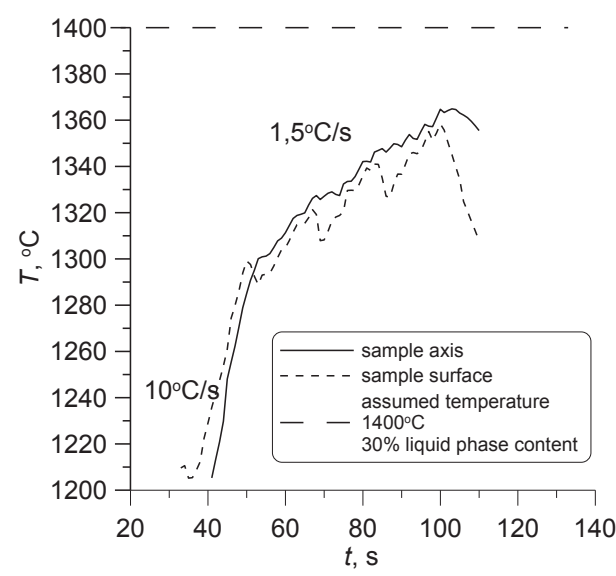

c)

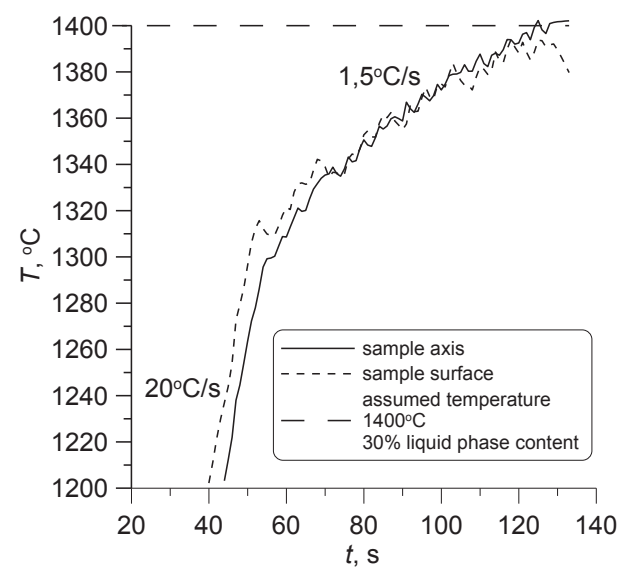

Fig. 8. Temperature of sample at axis and by lateral surface heated to $1400^{\circ} \mathrm{C}$, three trials with different heating velocities $(a, b, c)$ 
Examinations of the obtained samples with optical and scanning microscopes revealed the globular microstructure of the shaped material. A high rate of forming allowed the material solidification caused by a heat flow to cooler tools before the completion of the forming process to be avoided (Fig. 9). In addition, some efforts have been made to eliminate the temperature loss by preheating the steel mold to a temperature of about $600^{\circ} \mathrm{C}$. To this end, a resistance-heating element in the shape of a hoop embracing the mold was used. Electrical power was supplied through a dedicated gate embedded in the mold wall. Properly selected temperatures of the material and tools and the forming rate allowed for the correct microstructure and the initially assumed shape of the forgings to be obtained (Fig. 10).

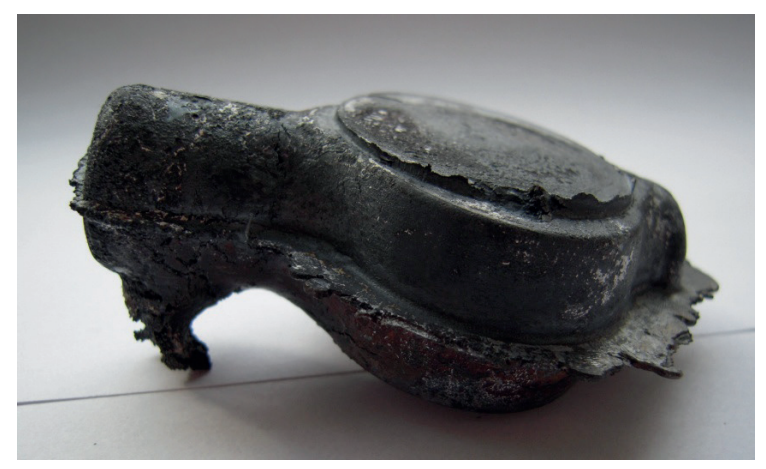

Fig. 9. Picture of die stamping of steel $100 \mathrm{Cr} 6(t H 15)$ shaped at $1400^{\circ} \mathrm{C}$ in the semi-solid state

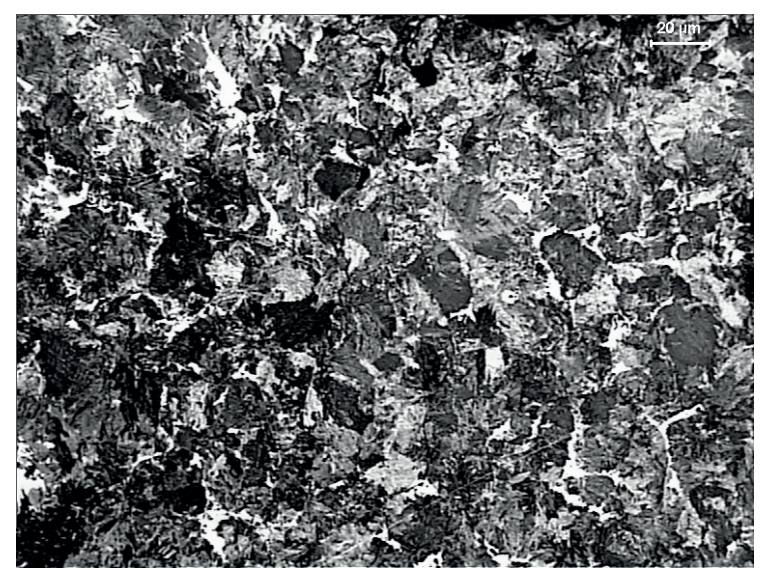

Fig. 10. Globular microstructure of a die stamping of steel $100 \mathrm{Cr} 6(\mathrm{tH} 15)$ shaped at $1400^{\circ} \mathrm{C}$ in the semi-solid state 


\section{Rheological analysis of high-melting-point alloys in the semi-solid state}

Next, the scientific objective was to precisely identify the rheological properties of the steel alloys. In this area, it was planned to both develop appropriate material tests and analyze the test results with suitable mathematical models. The reason for these actions was to acquire knowledge that could be used, among others, to optimize thixoforming processes, as well as to carry out numerical simulations of them. Knowledge of the rheological properties of semi-solid metal alloys is an essential factor from the perspective of the numerical modeling of these processes. For thixoforming, it allows us to correctly determine the mechanical parameters of the process and correctness of filling of the die cavity. The ultimate objective of this work were viscosity models of the selected steels alloy that could be applied in commercial simulation packages intended for the modeling of the metalforming processes. These models specifically describe the influence of key parameters (such as temperature or strain rate) on the material's viscosity. The planned research scope had a broader objective, not only restricted to formulating mathematical models of the viscosity. It included the rheological identification of the selected alloys from a wider perspective with regards to the influence of temperature and the non-dilatational strain rate.

Examinations of the rheological properties of the steel alloys carried out as part of the work were used for evaluating the possibilities for applying thixoforming for these alloys [18-22] The methodology of analyzing the rheological properties enabled material tests to be conducted for a broad range of forming parameter values. These parameters substantially impact the material behavior. The most-important of these parameters are temperature and shear rate (in the meaning of effective non-dilatational strain rate). The temperature influences the progress of the phase transformation related to the solidification process and determines the values of most of the thermophysical parameters of the alloys. Semi-solid metal alloys are non-Newtonian fluids; therefore, the influence of shear rate on the viscosity should also be determined. In turn, the impact of a forming time on the viscosity of semisolid metal alloys is related to the thixotropy effect, giving the name to this forming process.

Preparations of the material tests involved the selection of materials for the mold for the thixoforming processes. The main difficulty is the high melting temperature of the alloys, which imposes the need to apply materials with the appropriate properties. For the purposes of the material tests, there were attempts to make molds from graphite, ceramic materials $\left(\mathrm{Al}_{2} \mathrm{O}_{3}+\mathrm{ZrO}_{2}\right)$, and tool steel. Alundum tools were used for viscosity measurements. In this case, an addition of $\mathrm{ZrO}_{2}$ to $\mathrm{Al}_{2} \mathrm{O}_{3}$ was used to enhance the resistance to cracking under the thermal stress caused by rapid temperature changes.

The material tests was developed and conducted with a viscometer equipped with a high-temperature furnace. A device like this enables rheological properties to be measured for high values of the liquid phase content. The designed and conducted experiments were unique. The upsetting tests in the solid and semi-solid state could be also 
considered. Unfortunately, the dies shape prevented tests from being conducted at higher temperatures ensuring the liquid phase content above $10 \%$.

From the point of view of continuum mechanics, the results obtained within the confines of the upsetting and rheometric tests are complementary [23]. There is a strict relationship between the values measured with these tests; i.e., flow stress $\sigma$ and viscosity $\eta$ (1):

$$
\eta(T, \dot{\bar{\varepsilon}})=\frac{\sigma(T, \dot{\bar{\varepsilon}})}{3 \cdot \dot{\bar{\varepsilon}}}
$$

The obtained results were analysed, including the development of visco-plastic rheological model (2) of the steel examined. To this end a computer program for the identification of model parameters was written. The method applied in this program allows the error function between the measured and calculated stress values to be minimized. The Rosenbrock method was used for the optimisation. The conducted tests enabled, among others, parameters of thixoforming experiments to be defined.

$$
\eta=\eta_{0} \cdot(K, \dot{\gamma})^{n} \quad \dot{\gamma} \geq \dot{\gamma}_{0} ; \quad \eta=\eta_{0} \cdot\left(K, \dot{\gamma}_{0}\right)^{n} \quad \dot{\gamma}<\dot{\gamma}_{0}
$$

Tools in the form of cups and rods with appropriately selected diameters to eliminate turbulent flow (a low value of the Reynolds number) also allow us to analyze the properties present at high non-dilatational strain rates. As part of this stage of work, cylindrical alundum tools (cups and rods) characterized by corrugated surfaces preventing the alloy tested from sliding at higher viscosity values were designed. The measurement procedure was also designed so as to enable the parameters of the rheological model applied in thixoforming simulations using the software ProCAST to be determined. This software is based on a Power Cut-off Model (2) in which a limit value of non-dilatational strain rate occurs $\dot{\gamma}_{0}$, in order to model the thixotropic effect [24]. The measurement of selected steels viscosity was carried out. Also the rheological model for $100 \mathrm{Cr} 6$ steel alloy was developed. Figure 11 shows a graph of viscosity of $100 \mathrm{Cr} 6$ steel as a function of non-dilatational strain rate for the selected temperatures.

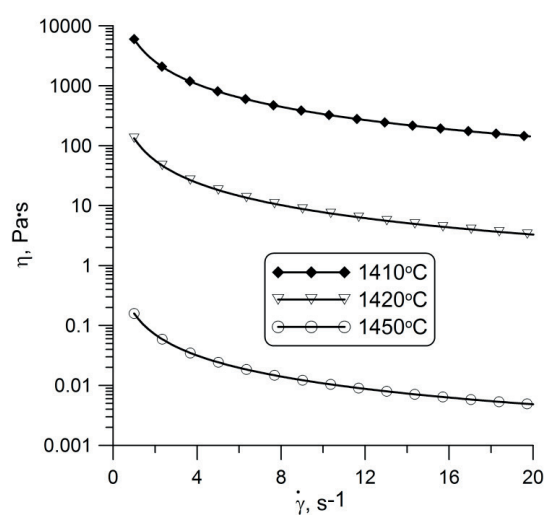

Fig. 11. Viscosity curves $[\mathrm{Pa} \cdot \mathrm{s}]$ versus non-dilatational strain rate [-] for steel $100 \mathrm{Cr} 6(\lfloor\mathrm{H} 15)$ 
In fact, liquid and semi-solid metals are non-Newtonian fluids. Their viscosity is highly variable as a function of the non-dilatational strain rate. The research confirmed that metals in these states are shear-thinning fluids. This thesis is proven by Figure 11. From the perspective of the numerical modeling of flows in semi-solid processes, taking into account the dependence of viscosity on shear rate allows us to substantially improve the solution accuracy. Analyzing the graphs in Figure 11, viscosity within the range of shear rate change from $1 \mathrm{~s}^{-1}$ to $20 \mathrm{~s}^{-1}$ changes on average by one order of magnitude. The conducted tests enabled, among others, parameters of pilot thixoforming processes of $100 \mathrm{Cr} 6$ steel to be established.

It should be emphasized that rheometric tests are innovative and unique due to their temperature range. Thanks to these experiments, we can learn the exact value of steel viscosity in the semi-solid state. The available published data seems to be incomplete. For instance, Figure 12 presents a comparison of the viscosities of steel $100 \mathrm{Cr} 6$ determined experimentally and with the material databases of the ProCAST package (module Visual-Cast, version 10.0.1). This database allows the values of viscosity to be determined on the basis of chemical composition as only a function of temperature, which simplifies the semi-solid steel model to the Newtonian fluid model. The calculations were made for the liquid and solid phase proportions arising from the thermodynamic equilibrium in accordance to the lever-rule principle.

a)

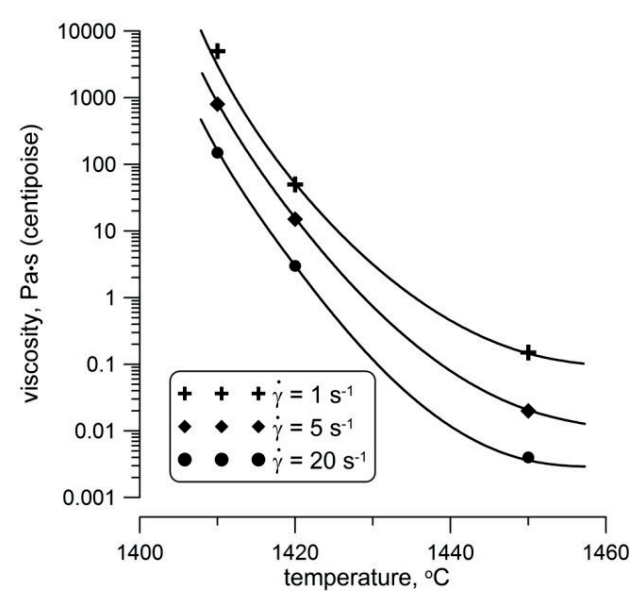

b)

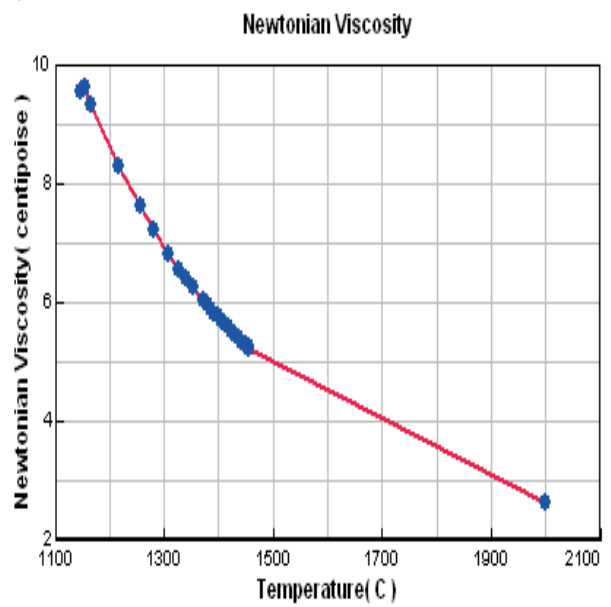

Fig. 12. Comparison of values of viscosities of steel 100Cr6: a) determined experimentally; b) with material databases of ProCAST package (module Visual-Cast, version 10.0.1)

Similar results were obtained for the steels analyzed in papers [21] (S235JR (acc. PN-EN 10025-2:2007), S320GD (acc. PN-EN 10346:2011), B500SP (acc. PN-H-93220:2006), electro technical steel). 
The viscosity of the steels examined were described with the Carreau-Yasuda Equation (3) [21]:

$$
\eta=\eta_{\infty}+\left(\eta_{0}-\eta_{\infty}\right) \cdot\left[1+(\lambda \cdot \dot{\gamma})^{\alpha}\right]^{\frac{n-1}{\alpha}}
$$

where:

$$
\begin{aligned}
& \dot{\gamma} \text { - strain rate, } \\
& \eta_{0} \text { - zero strain rate viscosity, } \\
& \eta_{\infty} \text { - infinite strain rate viscosity, } \\
& \lambda \text { - phase shift, } \\
& n \text { - power law coefficient, } \\
& \alpha \text { - Yasuda coefficient. }
\end{aligned}
$$

a)

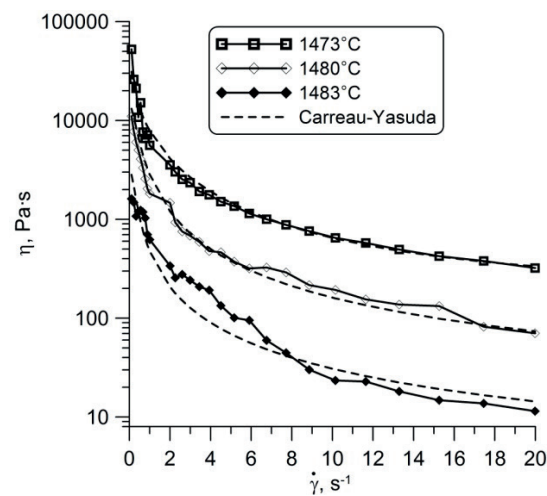

c)

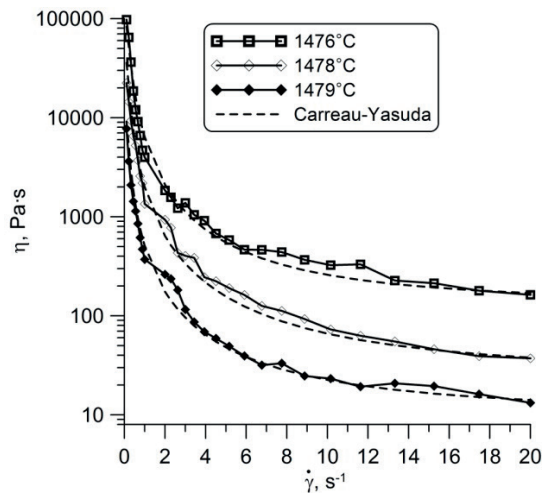

b)

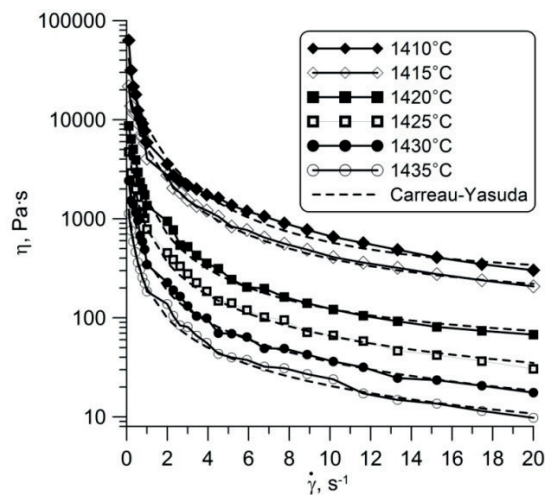

d)

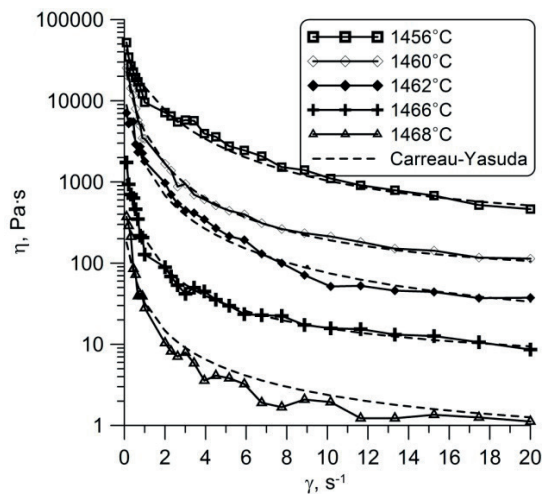

Fig. 13. Viscosity curves versus non-dilatational strain rate determined experimentally for steel: a) S235JR; b) electro technical steel; c) S320GD; d) B500SP

The measurement procedure enables the viscosity differences to be precisely captured for a narrow band of very high temperatures. This situation is illustrated in Figure 13, where the results of the viscosity measurements for low-carbon steel B500SP are 
presented. Obtained results of viscosity measurements of constructional steels show that application the thixoforming processes for shaping these steels is rather difficult due to narrow semi-solid temperature range. This is the reason, why thixoforming processes were no longer considered as the method of shaping these steels.

The values of the parameters of the Carreau-Yasuda model for the analyzed steel alloys are shown in Tables 1-4. The approximation was carried out using the least squares method implemented in the specially developed software where optimization methods were applied. The obtained values dependent on temperature can be directly applied in the ProCAST software and used in the numerical simulations of the casting processes.

Table 1. Parameters values of Carreau-Yasuda model for S235JR steel

\begin{tabular}{|c|c|c|c|c|c|}
\hline $\mathbf{S 2 3 5 J \mathbf { R }}$ & $\eta_{\mathbf{0}}[\mathrm{Pa} \cdot \mathbf{s}]$ & $\eta_{\infty}[\mathrm{Pa} \cdot \mathbf{s}]$ & $\lambda_{k}[\mathbf{s}]$ & $\alpha$ & $\boldsymbol{n}$ \\
\hline $1473^{\circ} \mathrm{C}$ & $80,000.00$ & 200.000 & 0.1 & 0.43 & -2.24 \\
\hline $1480^{\circ} \mathrm{C}$ & $14,014.00$ & 13.880 & 3.2 & 2.00 & -0.30 \\
\hline $1483^{\circ} \mathrm{C}$ & $3,000.00$ & 2.000 & 4.5 & 2.50 & -0.22 \\
\hline $1485^{\circ} \mathrm{C}$ & 500.00 & 0.200 & 5.5 & 3.00 & -0.15 \\
\hline $1500^{\circ} \mathrm{C}$ & 10.00 & 0.007 & 8.0 & 4.00 & -0.09 \\
\hline
\end{tabular}

Table 2. Parameters values of Carreau-Yasuda model for electro technical steel

\begin{tabular}{|c|c|c|c|c|c|}
\hline $\begin{array}{c}\text { Electro tech- } \\
\text { nical steel }\end{array}$ & $\eta_{\mathbf{0}}[\mathrm{Pa} \cdot \mathbf{s}]$ & $\eta_{\infty}[\mathrm{Pa} \cdot \mathbf{s}]$ & $\lambda_{k}[\mathbf{s}]$ & $\alpha$ & $\boldsymbol{n}$ \\
\hline 1410 & $100,080.0$ & 250.00 & 0.5 & 0.52 & -1.50000 \\
\hline 1415 & $30,073.0$ & 120.00 & 2.0 & 0.90 & -0.52972 \\
\hline 1420 & $10,028.0$ & 40.00 & 4.0 & 1.69 & -0.29812 \\
\hline 1425 & $5,011.9$ & 10.00 & 5.0 & 2.52 & -0.15000 \\
\hline 1430 & $2,503.9$ & 2.00 & 6.0 & 3.50 & -0.05000 \\
\hline 1435 & $1,300.0$ & 1.00 & 6.6 & 3.80 & -0.00100 \\
\hline 1460 & 20.0 & 0.30 & 9.0 & 4.00 & -0.00010 \\
\hline 1470 & 1.0 & 0.03 & 10.0 & 4.10 & -0.00005 \\
\hline
\end{tabular}


Table 3. Parameters values of Carreau-Yasuda model for S320GD steel

\begin{tabular}{|c|c|c|c|c|c|}
\hline S320GD & $\eta_{0}[\mathrm{~Pa} \cdot \mathbf{s}]$ & $\eta_{\infty}[\mathrm{Pa} \cdot \mathbf{s}]$ & $\lambda_{k}[\mathbf{s}]$ & $\alpha$ & $\boldsymbol{n}$ \\
\hline $1476^{\circ} \mathrm{C}$ & $100,000.00$ & 130.00 & 5.0 & 2.00 & -0.70 \\
\hline $1478^{\circ} \mathrm{C}$ & $40,000.00$ & 25.00 & 6.0 & 3.00 & -0.68 \\
\hline $1479^{\circ} \mathrm{C}$ & $10,000.00$ & 10.000 & 6.5 & 3.50 & -0.60 \\
\hline $1480^{\circ} \mathrm{C}$ & 30.00 & 2.000 & 6.8 & 3.80 & -0.10 \\
\hline $1500^{\circ} \mathrm{C}$ & 7.00 & 0.001 & 15.0 & 5.00 & -0.01 \\
\hline
\end{tabular}

Table 4. Parameters values of Carreau-Yasuda model for B500SP steel

\begin{tabular}{|c|c|c|c|c|c|}
\hline B500SP & $\eta_{\mathbf{0}}[\mathrm{Pa} \cdot \mathbf{s}]$ & $\eta_{\infty}[\mathrm{Pa} \cdot \mathbf{s}]$ & $\lambda_{\boldsymbol{k}}[\mathbf{s}]$ & $\alpha$ & $\boldsymbol{n}$ \\
\hline $1456^{\circ} \mathrm{C}$ & $55,000.00$ & 300.00 & 0.55 & 0.78 & -1.15 \\
\hline $1460^{\circ} \mathrm{C}$ & $30,055.00$ & 65.00 & 2.40 & 1.10 & -0.70 \\
\hline $1462^{\circ} \mathrm{C}$ & $11,000.00$ & 10.0000 & 3.00 & 1.30 & -0.50 \\
\hline $1466^{\circ} \mathrm{C}$ & $1,200.00$ & 5.0000 & 4.02 & 1.88 & -0.27 \\
\hline $1468^{\circ} \mathrm{C}$ & 200.40 & 0.4540 & 4.10 & 1.90 & -0.25 \\
\hline
\end{tabular}

\section{Numerical simulation of steel thixoforming process}

Within the confines of the work the ProCAST software was applied for identification of temperature range of thixoforming process. In order to obtain precise results of simulation an application of proper material properties is necessary. Among other things the rheological model developed on the basis of viscosity measurements (Fig. 11) was applied. In order to do this it is necessary to fill special window of the software (Fig. 14) where definition of the rheological model (2) is possible.

High piston velocity allows to avoid the solidification of the material before complete dies filling. Distribution of temperature at the and of dies filling is shown in Figure 15.

On the basis of the pressure values inside shaped alloy (Fig. 16) it is possible to determine the piston forces (Fig. 17). This way the determination of the temperature range of thixoforming process could be possible. The maximum force equals $10 \mathrm{kN}$ was assumed. Thus the minimal material temperature equals $1390^{\circ} \mathrm{C}$. 


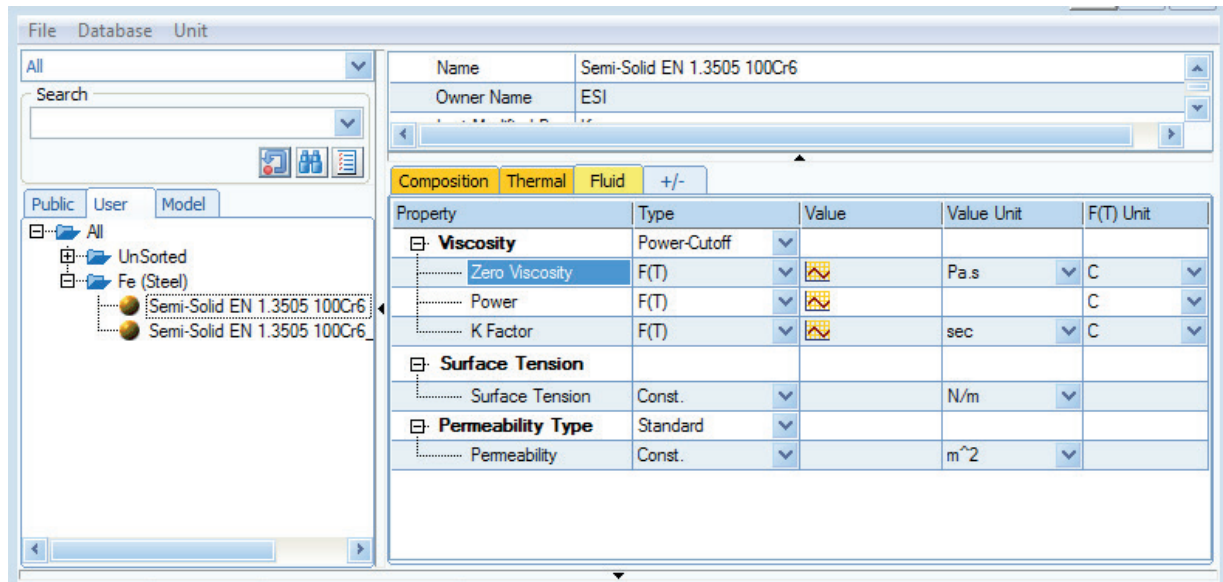

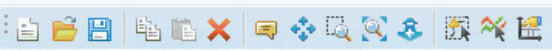
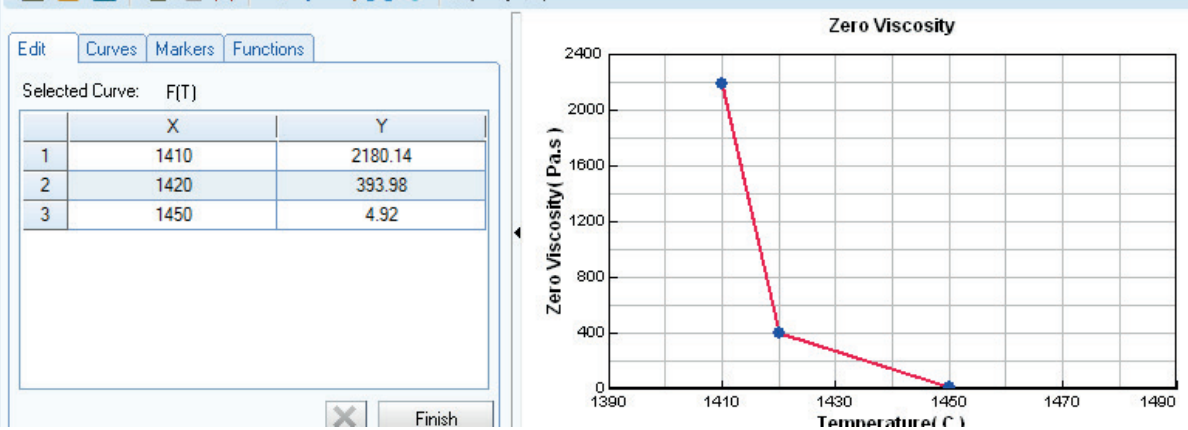

Fig. 14. Window of ProCAST software used for implementation of material models

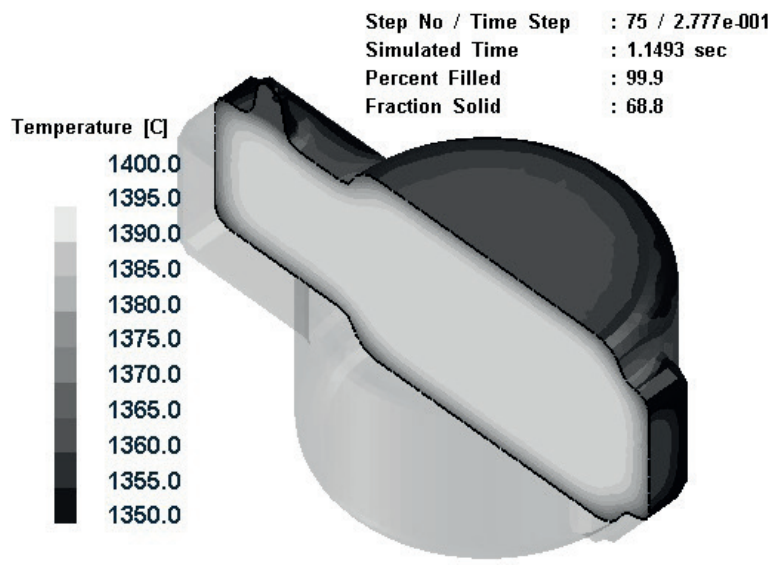

Fig. 15. Distribution of temperature at the and of dies filling 


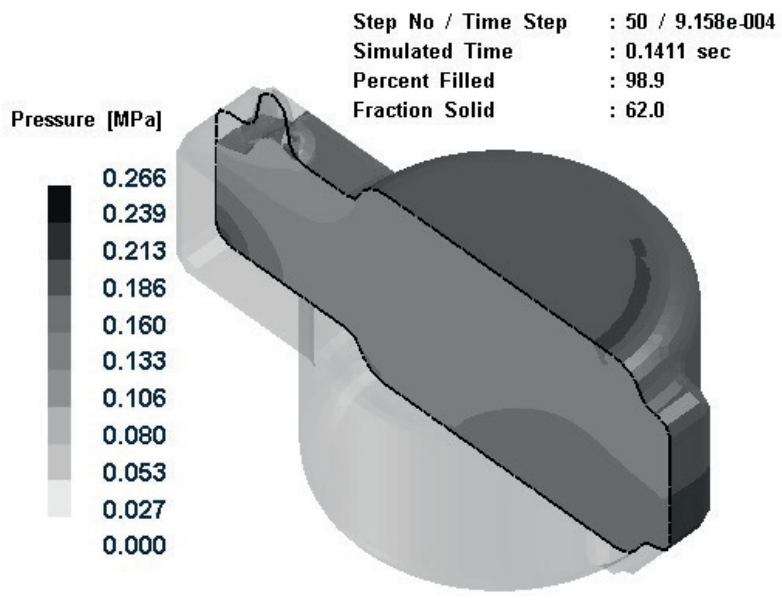

Fig. 16. Distribution of pressure at the and of dies filling

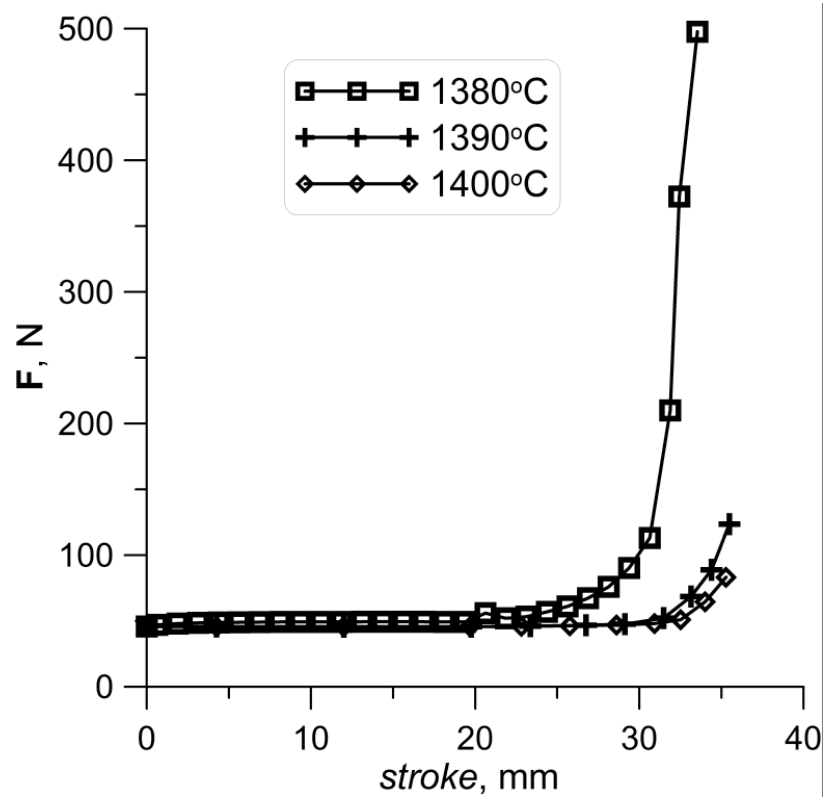

Fig. 17. Force curves versus piston stroke for three different initial temperature of the 100Cr6 alloy 


\section{Conclusions}

Generally, an interdisciplinary methodology of designing thixoforming processes of high-melting metal alloys was developed. It was illustrated by the application of the selected tool steels to obtain stampings with a complex shape. In order to control the microstructure of semi-solid alloys, evaluate their fluidity, and understand their constitutive behavior, the linked analyses and fundamental research were taken into account.

The conditions for forming a globular structure in high-melting metal alloys [the SW7M (HS6-5-2), NC11 (X210Cr12), ŁH15 (100Cr6) steel alloys] were analyzed. The conducted analysis confirmed the possibility of using two methods. Their common feature is heating to the semi-solid state from the solid state. However, these methods differ with the method of refinement of the microstructure (the SIMA method and spray casting).

A rheological identification of the high-melting metal alloys was carried out. The visco-plastic properties, were identified. Rheological models of the selected alloys were developed. The methodology of the rheological identification of high-melting metals in the semi-solid state was described. As part of this work, cups and rods for a viscometer were designed to enable the viscosity of the metal alloys to be measured precisely. An application of mathematical models to describe the rheology of the metals in the liquid and semi-solid states was shown.

Physical simulations and determination of conditions for the thixoforming of the steels $Ł \mathrm{H} 15$ (100Cr6)] were carried out. By an industrial validation of the steel thixoforming process, it was shown that the applied approach is effective and allows us to effectively design the forming processes of high-melting metals in the semi-solid state, including the proper selection of equipment and determination of the temperature and force process parameters. The work included successful trials of physical simulations of thixoforming that can be a foundation for further application work.

A numerical model of the resistance heating process in a commercial program ADINA based on the finite element method was developed. This model simulates the heating of steel samples caused by a high intensity electrical current flow. In the solution, the Joule-Lenz law is substituted for the heat source in the Fourier equation. This model includes the thermal effect of the phase change related to the solidification process as well as the heat transfer between individual components of the system.

\section{Acknowledgements}

Publication financed through statutory funds of AGH University of Science and Technology in Krakow “Analiza zjawisk zachodzących w cieczach metalurgicznych”, No. 11.11.110.502. 


\section{Appendix}

This paper is the publication from a thematically related series from the process of conferment of the degree of doktor habilitowany to Dr. Krzysztof Sołek pursuant to the rules laid down in Ustawa z dnia 14 marca 2003 r. o stopniach naukowych i tytule naukowym oraz stopniach i tytule w zakresie sztuki (Dz. U. $2003 \mathrm{nr} 65$ poz. 595) [the Act of March, 14, 2003, on Academic Degrees and Title and Degrees and Title in the Arts with later changes (Republic of Poland law)]. This series concerns the thixoforming of highmelting-point metal alloys.

\section{References}

[1] Rassili A., Robelet M.: Industrialization. In: Atkinson H.V., Rassisli A. (eds.), Thixoforming Steel. Shaker Verlag, Aachen 2010, 87-103

[2] Kapranos P.: Semi-Solid Metal Processing - A Process Looking for a Market. Solid State Phenomena, $141-143(2008), 1-8$

[3] http://exocor.com/downloads/product-datasheets/Stellite-21-Datasheet.pdf [26.09.2017]

[4] Kapranos P.: Routes to Thixoformable Starting Material. In: Atkinson H.V., Rassili A. (eds.), Thixoforming Steel. Shaker Verlag, Aachen 2010, 13-36

[5] Spencer D.B., Mehrabian R., Flemings M.C.: Rheological behavior of Sn-15 pct Pb in the crystallization range. Metallurgical Transactions, 3 (1972), 1925-1932

[6] Young K.P., Kyonka C.P., Courtois J.A.: Fine grained metal composition, US Patent no. 4,415,374, 30 March, 1982

[7] Kirkwood D.H., Sellars C.M., Elias Boyed L.G.: Thixotropic materials, European Patent no. 0305375 B1, 28 October, 1992

[8] Kenney M.P., Courtois J.A., Evans R.D., Farrior G.M., Kyonka C.P., Koch A.A., Young K.P.: Metals Handbook, vol. 15 (1988), ASM International, Metals Park, Ohio, 327-338

[9] Garat M., Blais S., Pluchon C., Loué W.R.: Aluminium semi-solid processing: From the billet to the finished part. In: Kumar Bhasin A. (ed.), Proceedings: 5th International Conference, Semi-Solid Processing of Alloys and Composites: Golden, Colorado, USA, June 23-25, 1998, 17-31

[10] Zillgen M., Hirt G.: Microstructural effects of electromagnetic stirring in continuous casting of various aluminium alloys. In: Kirkwood D.H., Kapranos P. (eds.), Conference proceedings: 4th International Conference, Semi-Solid Processing of Alloys and Composites, 19-21 June 1996, the University of Sheffield, England, 180-186

[11] Mathur P., Apelian D., Lawley A.: Analysis of the spray deposition process. Acta Metallurgica, 37, 2 (1989), 429-443

[12] Barnes H.A.: Thixotropy - A Review. Journal of Non-Newtonian Fluid Mechanics, 70 (1997), 1-33

[13] Sołek K.P., Dutkiewicz J., Rogal $Ł .:$ Analysis of thixoforming process and microstructure development of steel in semi-solid state. Steel Research International, 79 (2008), 239-246

[14] Sołek K., Mitura Z., Karbowniczek M., Dutkiewicz J., Faryna M., Rogal Ł.: Microstructure evolution in hot worked steel after heating to semi-solid state. Journal of Microscopy, 237, 3 (2010), 469-474

[15] Dutkiewicz J., Rogal Ł., Sołek K., Mitura Z.: Thixoforming technology of high carbon X210CrW12 steel. International Journal of Material Forming, 2, 1 (2009), 753-756

[16] Dutkiewicz J., Rogal Ł., Sołek K., Mitura Z., Kapranos K.: Thixoforming of spray formed M2 tool steel. International Journal of Material Forming, 3, 1 (2010), 755-758 
[17] Sołek K.P., Rassili A., Pierret J.C., Vaneetveld G.: Characterization of thixoforming process of $100 \mathrm{Cr} 6$ steel. Transactions of Nonferrous Metals Society of China, 20, 3 (2010), 916-920

[18] Sołek K., Korolczuk-Hejnak M., Karbowniczek M.: An analysis of steel viscosity in the solidification temperature range. Archives of Metallurgy and Materials, 56, 3 (2011), 593-598

[19] Sołek K., Korolczuk-Hejnak M., Ślęzak W., Karbowniczek M.: An analysis of HS6-5-2 steel viscosity in the semi-solid state. In: Menary G. (ed.), The 14th International ESAFORM Conference on Material Forming: ESAFORM 2011 Proceedings. Queen's University, Belfast, Northern Ireland, April 27-29, 2011. AIP Conference Proceedings, 1353, 1 (2011), 1033-1038

[20] Sołek K., Korolczuk-Hejnak M., Ślęzak W.: Viscosity Measurements for Modeling of Continuous Steel Casting. Archives of Metallurgy and Materials, 57, 1 (2012), 333-338

[21] Sołek K.P., Ślęzak W., Karbowniczek M.: Determination of rheological properties for numerical modelling of liquid steel flow inside continuous casting mould. In: Dziubiński M., Antosik K. (eds.), Rheology Theory and Application, Vol. 2, EKMA Krzysztof Antosik, Warszawa 2011, 269-282

[22] Sołek K.: Identification of the steel viscosity and dynamic yield stress for the numerical modelling of casting simulations in the semi-solid state. Archives of Metallurgy and Materials, 62, 1 (2017), 195-200

[23] Perzyna P.: Fundamental problems in visco-plasticity. Advances in Applied Mechanics, 9 (1966), 243-377

[24] Orgéas I., Gabathuler J.P., Imwinkelried T.H., Paradies Ch., Rappaz M.: Modelling of semi-solid processing using a modified temperature-dependent power-law model. Modelling and Simulation in Materials Science and Engineering, 11, 4 (2003), 553-574 